\title{
Implementation of Value Stream Mapping to reduce Lead Time in manufacturing of wireharness
}

\author{
B M Shivanand ${ }^{1}$, C S Chethan Kumar², Deepak Kumar ${ }^{3}$ \\ ${ }^{1}$ Student, M.Tech, Department of Industrial Engineering \& Management, MSRIT, \\ Bangalore, Karnataka-560054, India \\ ${ }^{2}$ Associate Professor, Department of Industrial Engineering \& Management, \\ MSRIT, Bangalore, Karnataka-560054, India \\ ${ }^{3}$ Assistant Professor, Department of Industrial Engineering \& Management, \\ MSRIT, Bangalore, Karnataka-560054, India \\ ${ }^{1}$ ID: bmshivanand2015@gmail.com, ${ }^{2}$ ID: chethan.tpm@gmail.com, ${ }^{3}$ ID: deepak.kr246@gmail.com
}

\begin{abstract}
Reduction of lead time for manufacturing wire harness for product select comfort using value stream mapping”, is designed to increase value added percentage by reducing lead time. The purpose of work is to improve the current state value stream map by eliminating non value added activities by using lean tools. The company was facing high manufacturing lead time and processing time which was leading to delay in meeting customer demands. The work was undertaken to address various issues and gaps observed during the work. The work involved conducting time study for the product Select comfort by collecting the Cycle time, Value added time, Lead time, Number of operators and number of delays.
\end{abstract}

Once after employing all above suggested tools and techniques in future state, the results were validated, wherein the lead time of the product is reduced by 3.4 days and processing time by $6.768 \%$ by eliminating the non value added activities.

Key Words: - Value added time, Cycle Time, Takt Time, Information flow

\section{INTRODUCTION}

A leading manufacturing company has a plant, which is involved in wire harness production. The aim of the plant is to reduce lead time of production and synergise various departments involved in production for better efficiency and achieve zero defect. The company was facing high manufacturing lead time and processing time which was leading to delay in meeting customer demands.

This study was conducted in the wire harness manufacturing company focusing on the production of a batch of harness for product "Select Comfort", which is used in Mechanised/Automatic smart bed system in Hospitals was scheduled to supply to high end international companies. The company consists of about 400 workers and operates for 6 days a week and 8 hours, 3 shift systems.

The entire business operations flow is as enumerated below. 


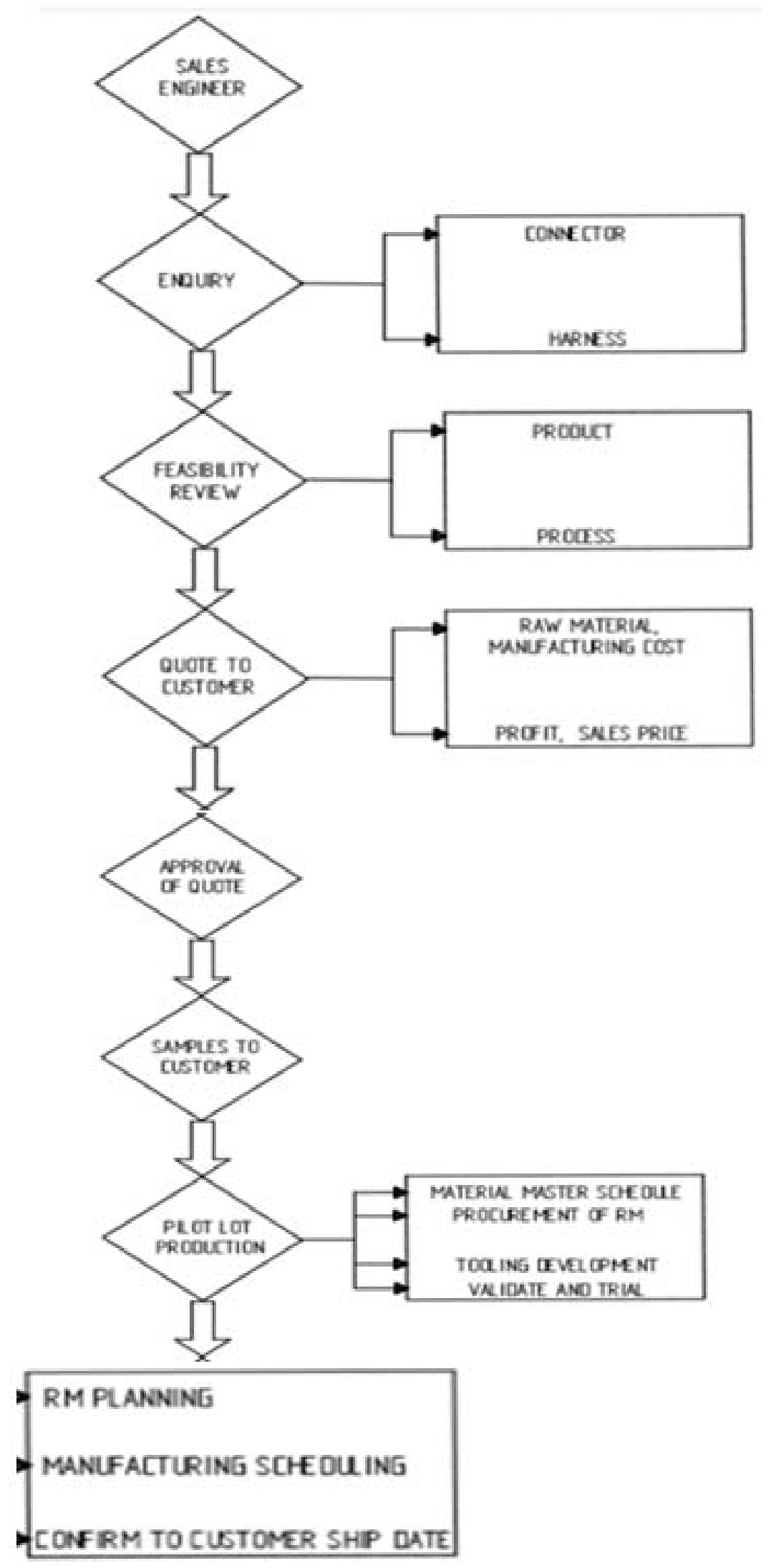

Fig 1: Business operation Flow 


\section{PROCESS FLOW}

Flow Process across various departments, in general, there are 12 main sections in this company. Raw materials are stored in a designated storage area and are located close to the manufacturing areas. Once the customer order is finalised as enumerated in below figure manufacturing process starts.

Following are respective departments where in the raw material is being converted into finished goods
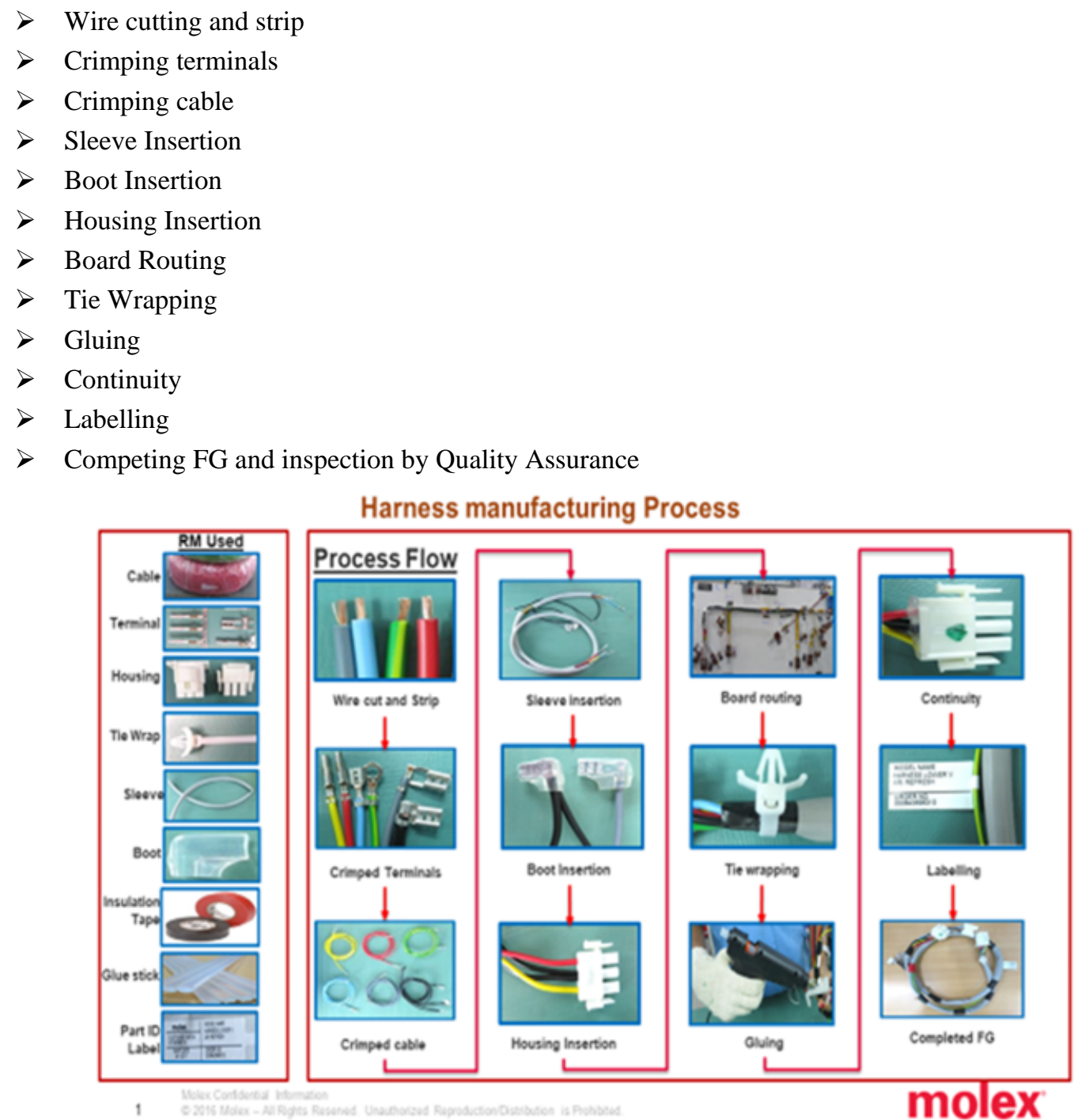

Fig 2: Harness manufacturing process

Problem formulation

The main problem across the company is higher lead time caused due to the traditional method of operation within the factory. The traditional method of manufacturing employs the push system, which permits unnecessary transportation, higher waiting times, excess raw material, over production, lack of communication, use of outdated methods and so on. Due to high lead times faced, company is confined from experiencing good customer loyalty, increased orders, increased profit margins,good reputation and less competition. Long lead times are drastically affecting the productivity of the organization. These reasons lead to frequent line setting; operators had to do overtime to meet the targets, meeting targets was found to be difficult due to extreme workload and high rate of rework with compromise in quality of work.

Due to the above stated reasons the productivity, efficiency and effectiveness of the workers, Quality of the products manufactured is reduced, thereby leading to an increase in lead time and rework. 


\section{OBJECTIVES}

1. Collection and segregation of data relating to the processes in the assembly line of production and drawing the current state Value Stream Map.

2. To reduce present high manufacturing lead time of 11.7 days to an acceptable period.

3. To reduce present high processing time of 1630.58 seconds to an acceptable time period.

4.To eliminate bottle necks like Routing and Continuity activity which is being done separately, $200 \%$-line inspection, inspection of cable and crimping, manual cutting activity.

5. Develop Future State Map so as to improve the flow of material in the existing processes to reduce waiting time and work in progress.

\section{LITERATURE REVIEW}

Tools and Techniques in Industrial Engineering

\section{Lean Manufacturing:}

Naidu and Chethan [1] have narrated that Lean manufacturing is a business model and collection of tactical methods that emphasize eliminating non-value-added activities (waste) while delivering quality products on time at least cost with greater efficiency. Lean also takes into account waste created through overburden ("Muri") and waste created through unevenness in workloads ("Mura"). Working from the perspective of the client who consumes a product or service, "value" is any action or process that a customer would be willing to pay for.

\section{Work Study:}

It is the systematic examination of the methods of carrying out activities [10] such as to improve the effective use of resources and to set up standards of performance for the activities carried out. Work design involves complex "people" relationships between operative staff, supervisors and specialists e.g. engineering managers and staff who commission new machines and maintain them.

\section{Operations research:}

As per International Journal for Quality Research [1], it is a discipline that deals with the application of advanced analytical methods to help make better decisions. It is often considered to be a sub-field of mathematics. Operations research is often concerned with determining the maximum (of profit, performance, or yield) or minimum (of loss, risk, or cost) of some real-world objective.

\section{Statistical process control (SPC):}

According to N Gopalakrishnan [5], author of Simplified Lean manufacturing Elements, Rules, Tools and Implementation.It is a method of quality control which uses statistical methods. SPC is applied in order to monitor and control a process. Monitoring and controlling the process ensures that it operates at its full potential.

5S:

$5 \mathrm{~S}$ was developed in Japan and stands for the Japanese words seiri (tidiness), seiton (orderliness), seiso (cleanliness), seiketsu (standardization), and shitsuke (discipline).

The list describes how to organize a work space for efficiency and effectiveness by identifying and storing the items used, maintaining the area and items, and sustaining the new order. [3].

\section{Six Sigma:}

Six Sigma is a set of techniques and tools for process improvement. Six Sigma seeks to improve the quality output of process by identifying and removing the causes of defects (errors) and minimizing variability in manufacturing and business processes. Each Six Sigma carried out within an organization follows a defined sequence of steps and has quantified value targets.

\section{Value Stream Mapping}

Carlo Scodanibbio; Value Stream Management: The road to Lean manufacturing through the value Stream mapping Technique [6] says that Value stream mapping is a lean-management method for analysing the current state and designing a future state for the series of events that take a product or service from its beginning through to the customer. At Toyota, it is known as "material and information flow mapping". It can be applied to nearly any value chain. 


\section{Why Value Stream Mapping Is an Essential Tool}

-It helps you visualize more than just the single process level, i.e. assembly, welding, etc., in production. -It helps you see more than waste. Mapping helps you see the sources of waste in your value stream.

-It provides a common language for talking about manufacturing processes.

-It makes decisions about the apparent, so you can discuss them. Otherwise, many details and decisions on your shop floor just happen by default.

•It ties together lean concepts and techniques, which help you avoid 'cherry picking'

\begin{tabular}{|c|c|c|c|c|c|c|}
\hline 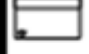 & process & $\triangle$ Inventory & ...P Push arrow & customer/st & upplier & \\
\hline$\Leftarrow$ & $\begin{array}{l}\text { Shipment } \\
\text { arrow }\end{array}$ & o. Shipment & $\begin{array}{l}\text { Production } \\
\text { control }\end{array}$ & $\begin{array}{l}\text { Manual } \\
\text { information }\end{array}$ & $\rightarrow$ & $\begin{array}{l}\text { Electronic } \\
\text { information }\end{array}$ \\
\hline & Data table & $\neg$ Timeline & Timeline & $\begin{array}{l}\text { Production } \\
\text { kanban }\end{array}$ & $D 2$ & $\begin{array}{l}\text { Withdrawal } \\
\text { kanban }\end{array}$ \\
\hline & Batch kanban & $\begin{array}{l}\text { batch } \\
\text { withdrawal }\end{array}$ & $\begin{array}{l}\text { Signal } \\
\text { kanban }\end{array}$ & Kanban post & $\exists$ & Supermarket \\
\hline & $\begin{array}{l}\text { Safety/Buffer } \\
\text { stock }\end{array}$ & $\equiv$ FIFO lane & ........ Pull arrow 1 & Pull arrow 2 & & Pull arrow 3 \\
\hline 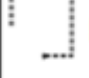 & Pull arrow 4 & $>$ Kaizen burst & Physical pull & $\begin{array}{l}\text { Sequenced } \\
\text { pull ball }\end{array}$ & 요 & Load leveling \\
\hline
\end{tabular}

Figure 3: Symbols used in value stream map

\section{How Literature Review has provided necessary input to this study}

Several journals have been reviewed to gain some ideas about the studies in the manufacturing industries and the usage of simulation techniques to analyse operational performance. It is noted that line balancing problems in assembly department is most popular operational issue in manufacturing or garment industry.

Line balancing in a manufacturing industry deals with allocation of man and machinery to the assembly line so that the precedence relation is satisfied and sum of task at any workstation does not exceed the cycle time. Simulation has been preferred tool to evaluate the performance of the production line as it has the ability to model dynamic and stochastic nature of productions system. It enables the researcher to gain the critical insights into the performance of a manufacturing company.

\section{Methodology}

The major problem witnessed across the assembly line unit of company is the higher waiting time between the different operations, leading to work getting piled up and thereby affecting the line efficiency. In order improve the productivity of the line the team set several goals.

One of the main goals was to create a future state VSM that illustrates a smooth material flow in the line. With the implementation of KAIZENS suggested in the VSM the waiting time should be reduced by at least 5\% and processing time around $10 \%$. The following step-by-step procedure was laid, to achieve our goals.

In order to accomplish the objectives following methods ware adopted

- $\quad$ Collect cycle time samples and analyse time study report.

- $\quad$ Observed processes during different times of the day.

- $\quad$ Obtained information from employees regarding the issues in the line and considered their suggestions.

- $\quad$ Bottleneck analysis using pitch diagram.

- $\quad$ Method study conducted to improve critical bottleneck operations.

- $\quad$ Use of Microsoft Visio to map current and future state. 


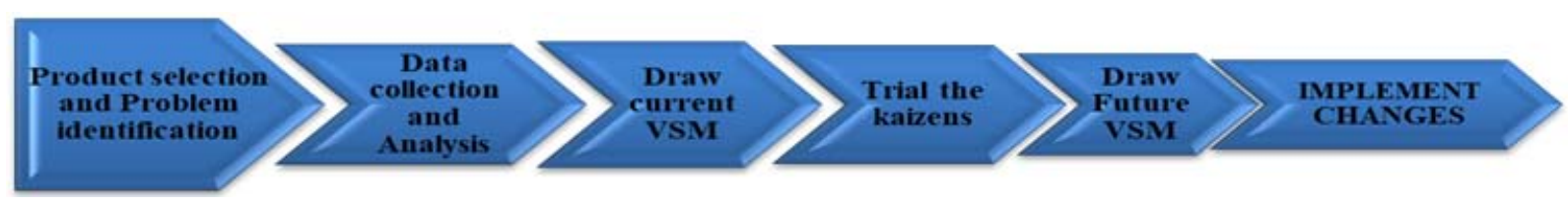

Figure 4: Work steps

\section{Data Collected}

\section{Data collection and analysis}

Operations Bulletin: It is a sheet containing the operations, their respective SAM, operators and machine requirement with part description. It varies from one-part style to another. Operations Bulletin is obtained from the time study conducted by the IE department and the master production schedule (MPS) by production planning and control (PPC) department.

Cycle Time: Cycle time for the operations in the assembly line was collected using a stop watch.

Gantt chart: This chart gives an overview of the processes, as and when a portion of activity is finished the horizontal bars are shaded. Several independent activities can start at the same time. The complete chart for processing the selected product with demand details is shown in below.

Table 1: Demand Details

\begin{tabular}{|c|c|c|c|}
\hline Material/Part no & $\begin{array}{c}\text { Demand per Year } \\
\text { (2019) }\end{array}$ & $\begin{array}{c}\text { Demand per month } \\
\text { (2019) }\end{array}$ & $\begin{array}{c}\text { Demand per week } \\
\text { (2019) }\end{array}$ \\
\hline 369100042 & 2140 & 178 & 45 \\
\hline 369100043 & 700 & 58 & 15 \\
\hline 369100017 & 7080 & 590 & 148 \\
\hline 369100018 & 9540 & 795 & 199 \\
\hline 369100019 & 19475 & 1623 & 406 \\
\hline 369100039 & 925 & 77 & 19 \\
\hline 369100040 & 2580 & 215 & 54 \\
\hline 369100037 & 3400 & 283 & 71 \\
\hline 369100038 & 25080 & 133 & 33 \\
\hline 369100017 & 1600 & 2090 & 523 \\
\hline 369100018 & 42640 & 3553 & 888 \\
\hline 369100019 & 44225 & 3685 & 921 \\
\hline TOTAL & $\mathbf{1 5 9 3 8 5}$ & $\mathbf{1 3 2 8 2}$ & $\mathbf{3 3 2 1}$ \\
\hline
\end{tabular}

\section{Current State VSM}

Developing a current state map begins with the analysis of the current production situations and drawing the current process flow chart for the selected family of product. Mapping begins from the assembly line.

The overall flow through the plant was observed and later changes the level of magnification; zooming in to map every individual step within a process category, or zooming out to encompass the value stream external to your plant. A set of standard symbols or icons are used to represent processes and flows.

The current state VSM is displayed is displayed below. For each process step recorded the variety of resources used in the step like operator requirement, cycle time for each operation and the range of times each resource is in use (represented as frequency) in a block of information specific to that step. As seen in the image, the total processing time for the assembly line, 1630.58 seconds excluding line setting, downtime. On the bottom of the map, the total cycle time and lead time are shown. The lead time is far greater than the processing time, thus increasing the lead time and operating costs due to high number of bottlenecks.

While developing the current state value stream map, one shift consisting of 8 hours is considered as one day since the factory operates at one shift per day. 


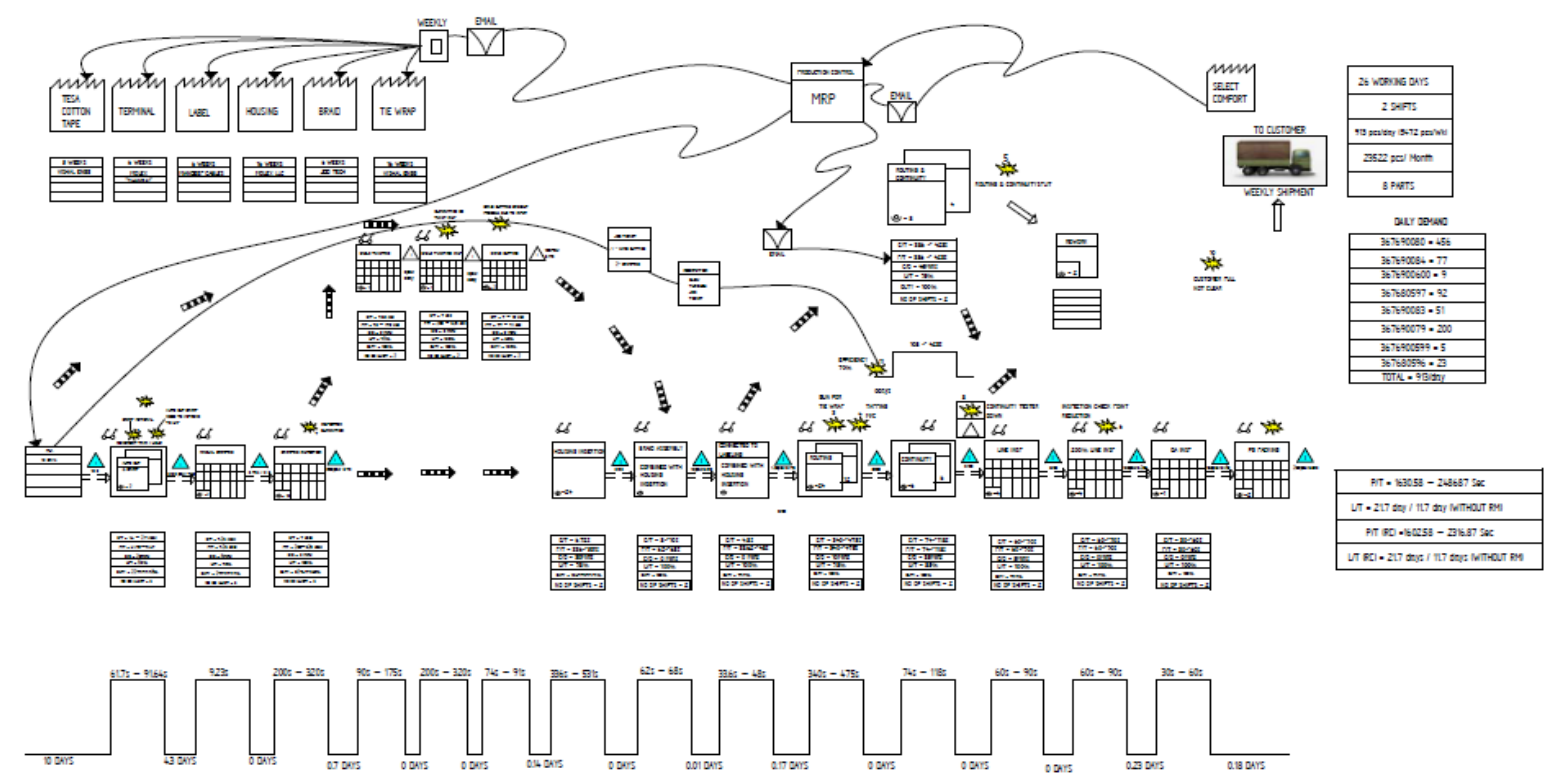

Fig 5: Current State

Analysis of the current state VSM and different methods for reducing the lead time -Kanban burst analysis - is enumerated below

1) Reduce Supplier lead time and constantly review order

2) Eliminating cable twisting inspection

3) Improve braid cutting Technology and effective Tie wrap and Tapping

5) Eliminating cable end crimping inspection

6) Reduce $200 \%$ line inspection

7) Achieve more than $90 \%$ line efficiency

8) Combine Routing and Continuity activity wherever possible

10) Reduce lead time of the product by initiating pull system

11) Reduce Packing time through automation

12) Line Balancing of parts of similar production activity 
FUTURE STATE VSM : SELECT COMFORT

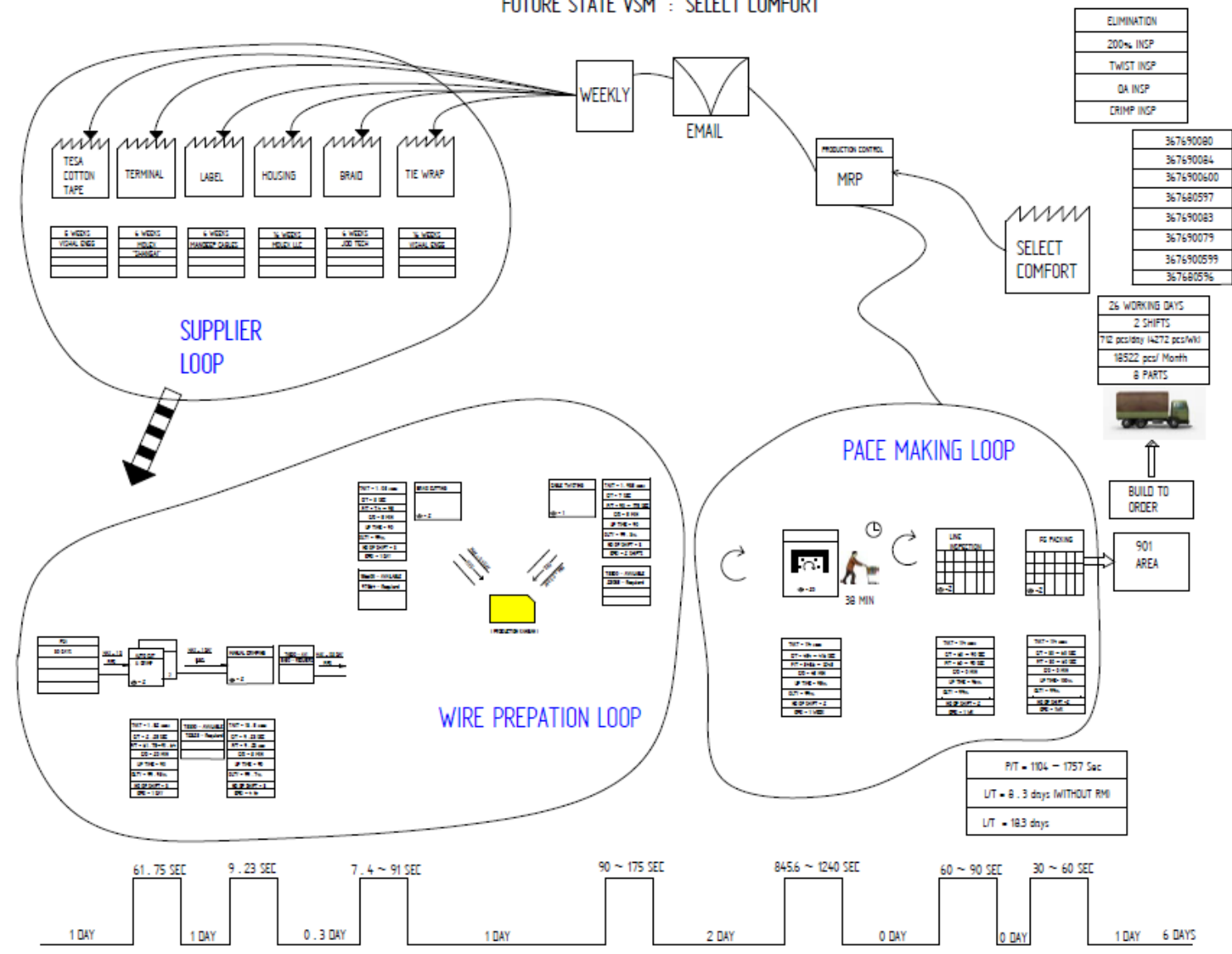

Fig 6: Future State

\section{Future State Value Stream Map}

The future value stream map shows the improvements to the value stream i.e. with the use of customized templates; lap seam folder at various bottle neck operations in the assembly line improves the line efficiency and output of these operations. Also, the processing time reduces by $6.768 \%$.and lead time by 3.4 days.

Some of the changes that can be found in the future state value stream map as compared to the current state value stream map are:

- $\quad$ The Lead time is reduced to 8.3 days from 11.7 days thereby saving 3.4 days.

- $\quad$ The Process time is reduced to 1104 seconds from 1630.58 seconds thereby a reduction of 526.58 seconds

- Value added percentage is estimated to increase by $10 \%$ after implementation of the stated suggestions.

- $\quad$ The Head Count (Manpower) is reduced to 31 from 60, thus saving expenditure on manpower

- It is observed that there is a better flow of material and information flow in the Future VSM

- $\quad$ Following activities are being eliminated

$>200 \%$ inspection

$>$ Cable Twisting inspection

$>$ QA inspection

$>$ Crimping inspection

Thus, there is an overall improvement in the process parameters.

\section{Future State: Line Balancing}

Line balancing is commonly technique to solve problems occurred in assembly line. Line balancing is a technique to minimize imbalance between workers and workloads in order to achieve required run rate. This can be done by equalizing the amount of work in each station and assign the smallest number of workers in the particular workstation. 
Reasons to have balance in the production line:

1) Keeping inventory costs low results in higher net income.

2) Keeping normal inventory levels lets the operator work all day long giving him/her the opportunity to earn more money by increasing his/her efficiency.

3) Keeping the line balanced lets the supervisors improve other areas because they can use their time better.

4) Balanced production keeps prices low which turns into repeat sales.

5) Balanced production means better production planning.

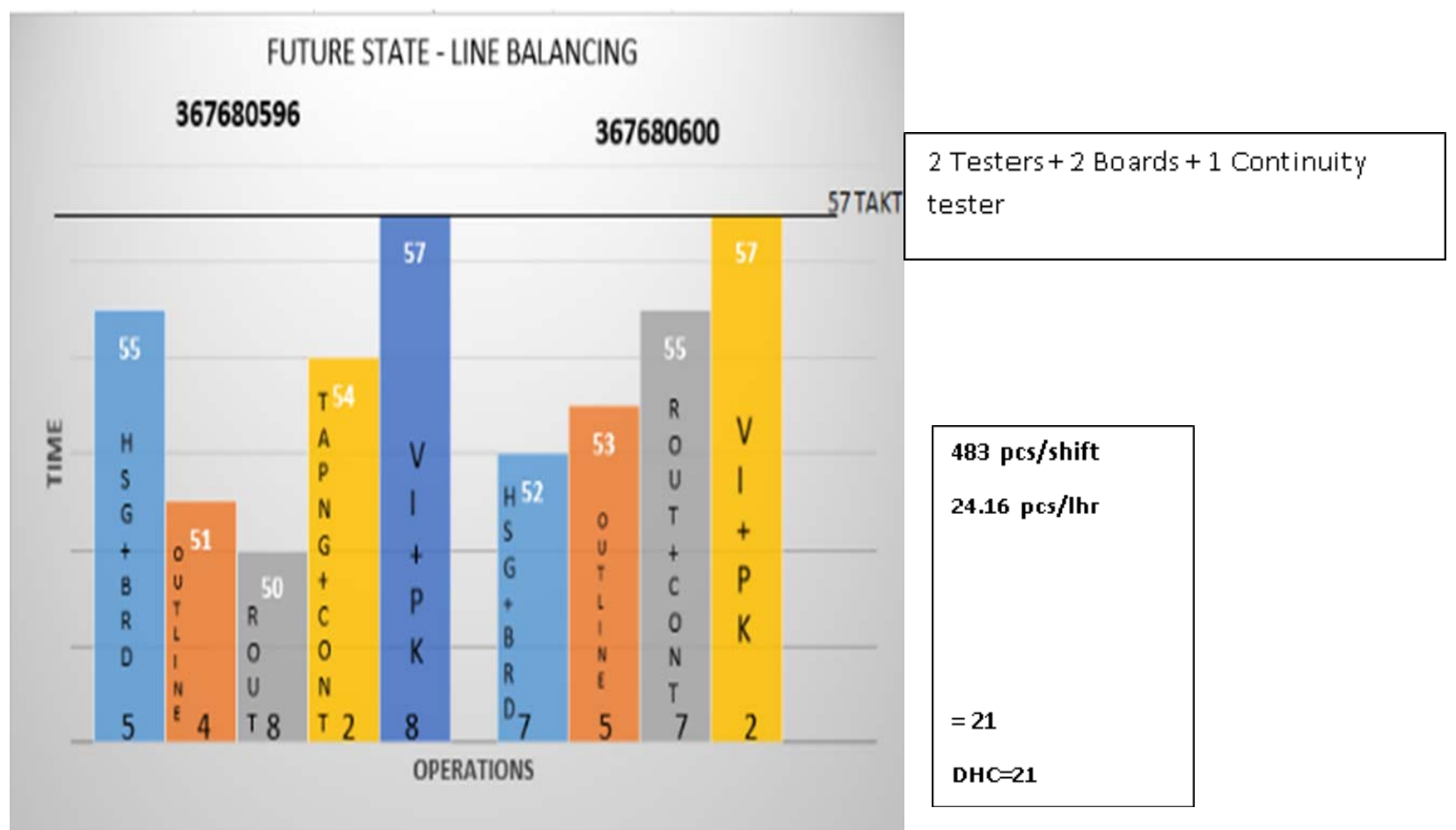

Fig 7: Line balancing Chart1

\section{Calculations:}

1) Takt time $=$ net available time/ customer demand

$$
\begin{aligned}
& =435 \text { minutes per day x } 60 \text { seconds } / 456 \text { pieces per day } \\
& =114 \text { per piece. }
\end{aligned}
$$

2) Total processing time of the current value stream map $=1630.58$ seconds.

Total processing time of the future value stream map $=1104$ seconds.

Hence change in the processing time $=526.58$ seconds.

Percentage decrease in the processing time $=6.768 \%$.

3) Man power cost savings

Total manpower deployed in current state $=60$

Total manpower deployed in Future state $=31$

Hence saving in manpower $=29$

Cost savings per day= 29 X 750= Rs 21750

Per year $=300 \times 21750=$ Rs6525000

\section{Result}

\section{RESULTS AND CONCLUSION}

The introduction of novel templates and fixtures has resulted in the reduction of the lead time by 3.4 days and processing time by $6.768 \%$. There is a substantial decrease in the manpower by $50 \%$ with a huge cost saving of Rs 652500 per year. This is depicted below in tabular form. 
Table 2: Result Comparison Table

\begin{tabular}{|l|l|l|}
\hline Nomenclature & Value added Time (P/T) & Production Lead Time \\
\hline Current State & $\mathbf{1 6 3 0 . 5 8 ~ S e c}$ & $\mathbf{1 1 . 7}$ days \\
\hline Future State & $1104 \mathrm{Sec}$ & $\mathbf{8 . 3}$ days \\
\hline Net Result & $\mathbf{5 2 6} \mathrm{Sec}$ & $\mathbf{3 . 4}$ days \\
\hline
\end{tabular}

\section{Conclusion:}

The overall Productivity of the line and the efficiency of the operators have increased. Better quality goods are manufactured leading to higher customer satisfaction. The percentage of rework and work load has considerably reduced. Better communication and flow have been established thereby increasing the productivity made by the organization.

\section{Scope for future improvement:}

After implementation, it was observed that, further enhancing quantity of the continuity tester by quantity one, can yield an improvement by 2 to 3 percent in the productivity and Lead time can be reduced by five percent. However, it increases the overall cost of production, as the cost of a continuity tester is approximately five to six lakhs. The continuous improvement in the skill levels of workers can also increase the rate of production.

The future study can be carried out in these directions so that the work flows along the line smoothly and production targets are met without any overtime or last-minute rush up.

\section{Contribution to the Society}

A multinational company is able to generate employment and enhance the skill level across various departments. Thus, contributing in enhancing the National GDP.

\section{REFERENCES}

[1] Dr C S Chethan \& Dr NVR Naidu (2012) Minimizing the eighth waste of lean absenteeism through Six Sigma methodology, International Journal for Quality research, UDK - 677:658.562(540), Vol.6, No. 2, 2012, pp 113-118

[2] Craig Woll, PhD 2009, Toyota Production System (TPS).

[3] Lonnie Wilson McGraw Hill (2009).How to implement Lean Manufacturing.

[4] William M Feld (2015) Lean Manufacturing tools, techniques and how to use them.

[5] N Gopalakrishnan (2009), Simplified Lean manufacturing Elements, Rules, Tools and Implementation.

[6] Carlo Scodanibbio (2009).Value Stream Management: The road to Lean manufacturing through the value Stream mapping Technique.

[7] Dilesh Patel, HermenRanpurin, Jayesh Shah and Jonathan Fournier (2010). The book of Value Stream Maps -I-2010.

[8] Martin, Karen; Osterling, Mike (2013). Value Stream Mapping: How to Visualize Work and Align Leadership for Organizational Transformation. New York, New York: McGraw Hill. p. 4. ISBN 9780071828918.

[9] Rother, Mike; Shook, John (2003). Learning to See: value-stream mapping to create value and eliminate muda. Brookline, MA: Lean Enterprise Institute. ISBN 0-9667843-08. 6

[10] Dr SK Sharma, Savita Sharma 2012.Work Study and Ergonomics.

\section{AUTHOR PROFILE}

Mr. B M Shivanand did his B.E (Mechanical) in Malnad College of Engineering, Mysore University, Hassan and MTech from MS Ramaiah Institute of Technology, affiliated to VTU BELGAUM. He is having 15 years of experience in Indian Air Force as engineering officer. At present he is an instructor in Air Force Technical College, Bengaluru, training young engineering officers.

Dr. Chethan Kumar did his B.E. in AIT Chikmanagalore, M.Tech in BEC, Bagalkot \& Ph.d under SVUCE, Tirupathi. He is having a rich experience of teaching (19 years), research (04 years) and industrial experience 1 year .He has published around 40 research papers in various national \& international Conferences and journals. He is life member of LMISTE \& LMIIIE. He has been invited as recourse person for various conference FDP and seminars. He has successfully completed a central government funded project. He has published two books namely industrial management and elements of mechanical engineering. Currently he is working as Associate Professor, Department of industrial Engineering \& Management, MSRIT, Bangalore-560054.

Mr. Deepak Kumar did his B.Tech in NIT SURAT, M.Tech in NIT TRICHY and pursuing Ph.D from VTU BELGAUM. He was the member of SAE-INDIA and ISTE. He has presented many paper in National \& International Conference, and published many papers in National \& International Journals. He is having 10 years experience in Teaching. Currently he is working as Asst. Professor in Department of Industrial Engineering \& Management, M.S Ramaiah Institute of Technology, Bangalore-560054. 